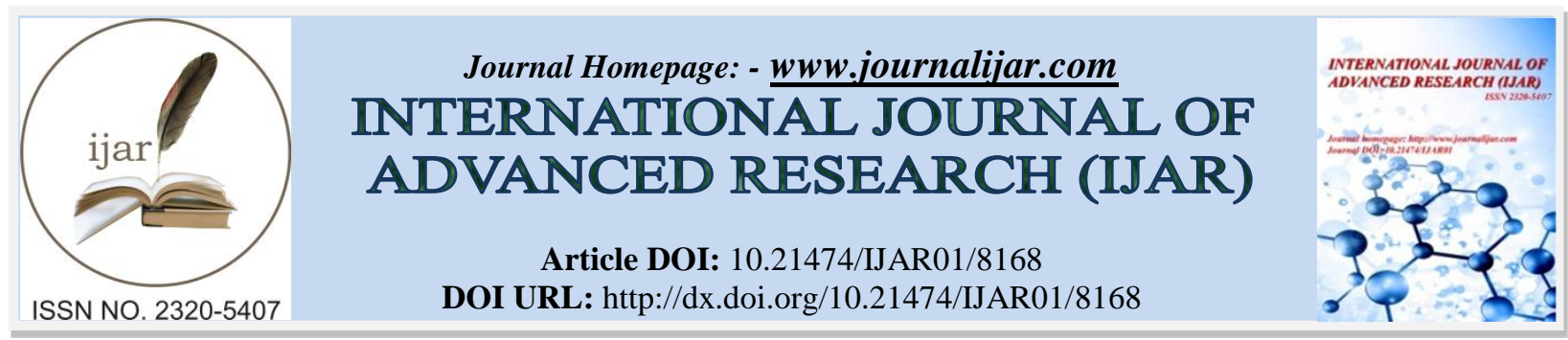

RESEARCH ARTICLE

\title{
THE EFFECT OF COMPETENCE OF HUMAN RESOURCES AND THE USE OF INFORMATION TECHNOLOGY ON THE QUALITY OF FINANCIAL REPORT WITH INTERNAL CONTROL SYSTEM AND ORGANIZATIONAL COMMITMENT AS MODERATION VARIABLE.
}

\author{
Stefani Marina Palimbong ${ }^{1}$, Yohanis Rura ${ }^{1}$ and Tawakkal ${ }^{3}$. \\ 1. Accounting Departement, Hasanuddin University. \\ 2. Accounting Departement, State Polytechnic of Ujung Pandang.
}

\section{Manuscript Info}

\section{Manuscript History}

Received: 08 October 2018

Final Accepted: 10 November 2018

Published: December 2018

\section{Keywords:}

competence of human resources, the use of information technology, internal control system, organizational commitment, quality of financial report.

\begin{abstract}
The aim of this research to examine the direct effect of competence of human resources and the use of information technology on the quality of financial report and examine the effect of internal control system and organizational commitment in moderating the competence of human resources and the use of information technology on the quality of financial report. This research used a quantitative approach conducted in the Regional Government of Tana Toraja Regency. The research objects were the apparatures of financial management at Tana Toraja Regency. The data were obtained using survey method and the instrument used was questionnaire. The sample consisted of 133 respondents using purposive sampling technique. The data were analyzed using moderated regression analysis processed using statistical package for the social sciences (SPSS v.22). The results of the research indicate that the competence of human resources and the use of information technology affect the quality of financial report . It also indicate that internal control system and organizational commitment can moderate the effect of competence of human resources and the use of information technology on the quality of financial report.
\end{abstract}

Copy Right, IJAR, 2018,. All rights reserved.

\section{Introduction:-}

The momentum of the reform era led to the increasing demands of the community for the implementation of clean, fair, transparent and accountable governance, in this case good governance and clean government. Financial report are structured reports regarding financial position and transactions carried out by reporting entities in a certain period (Peraturan Pemerintah No. 71, 2010). Financial report are the final product of the accounting process that has been carried out. Local Government Financial Reports are an important component for creating public sector accountability. Public accountability is the obligation of an agent (government) to manage resources, report, and disclose all activities and activities related to the use of public resources to the creditor (Mahmudi, 2010).

As an effort to realize a clean government, the local government is required to compile the Local Government Financial Report (LKPD). Criteria for assessing the quality of financial report according to Government Regulation No. 71 of 2010 concerning Indonesian Government Accounting Standards is relevant (has the benefit of feedback,

Corresponding Author:-Stefani Marina Palimbong.

Address:- Accounting Departement, Hasanuddin University. 
has predictive, timely, complete), reliable (honest, verifiable, neutrality) presentation, can be compared, and can be understood. The quality of financial report is the extent to which financial report provide true and honest information, this means that the quality of financial statements shows the concept of information quality from the report (Haliah, 2013).

Based on the audit report from the Supreme Audit Agency throughout the first semester of 2017 for the reporting year 2016. Badan Pemeriksa Keuangan (BPK) noted that there were still Local Government Financial Reports that had not yet obtained unqualified opinion (WTP) including the Tana Toraja Regency LKPD which received a qualified opinion (WDP) for the Year The 2016 budget in examining the financial statements of the local government of Tana Toraja Regency, BPK still found a condition that could be reported related to the problem of misrepresentation of accounts with SAP, where the cash balance of the expenditure treasurer was physically absent and there was a lack of cash in the expenditure treasurer. (www.bpk.go.id), the problem of administration and security of assets is not yet orderly and is still inadequate, the presentation of debt to a third party that has not been orderly because it is not supported by supporting documents so that the debt value in the balance sheet cannot be believed to be reasonable, revolving fund investments in the North Toraja regency are still recorded in the balance sheet of Tana Toraja Regency, the presence of OPD that compile financial reports are not in accordance with the applicable provisions where the balance of income, expenditure and cash cannot be believed which results in financial statements not providing relevant and reliable information. the process of determining APBD and APBD changes is not accurate (www.dprd-tanatorajakab.go.id).

This phenomenon shows that there are some accounts in the financial report that have not been presented and disclosed in accordance with Government Accounting Standards (SAP). Based on the phenomenon that occurs shows that the Financial Statements of the Tana Toraja Regency Government still do not meet the criteria for the required information. This phenomenon also contradicts the theory of stewardship, as assumed by the theory of stewardship that management is not motivated by individual goals but is aimed at the interests of the organization.

One of the steps taken by the local government in improving the quality of financial report is to improve the competence of human resources. Competence is the ability possessed by someone / individual both of knowledge, skills and behavior to do various tasks in a particular job. Financial reports are products produced by the field of science or from accounting disciplines, therefore competent human resources are needed, who are supported by a background in accounting education, often attend education and training or have experience in finance. If human resources carrying out the accounting system have competencies in the field of accounting, then these resources will use their knowledge and understanding in preparing financial statements in accordance with accounting principles and established rules so that they can produce quality financial reports. In line with this, Haliah et al. (2015) stated that human resources who are competent in accounting are needed to maintain the quality of financial statements as output from the field of accounting. This is in line with the results of the study, Herdianto (2015), Silviana and Zahara (2015), Simon et al., (2016) which concluded that human resource competencies proved to influence the quality of financial statements. But the results of these studies are different from the findings of Syarifudin (2014) and Rahmawati (2016) who concluded that human resource competencies did not affect the quality of financial statements.

Another factor that affects the quality of financial statements is the use of information technology. The regional government is currently obliged to develop and utilize advances in information technology that are useful for improving the ability to manage regional finance in accordance with Government Regulation Number 56 of 2005 concerning the Regional Financial Information System. Information technology includes computers, software, databases, internet networks, electronic commerce, and other types of technology (Wilkinson et al., 2000). Information technology that is increasingly advanced facilitates the implementation of financial information because it has the strength or potential in terms of consistency, accuracy, reliability, and the ability to store large amounts of data. The use of information technology will greatly help speed up the process of managing financial transaction data, presentation of financial statements, and can avoid mistakes in preparing financial statements so that it can produce quality financial statement information. This is supported by several previous studies, namely the study of Azlan et al. (2015) and Latjandu et. al (2016) who concluded that the use of information technology has a positive effect on the quality of financial statements. However, the results of these studies differ from the findings of Prapto (2010) and Andre (2017) who concluded that the use of information technology did not affect the quality of local government financial reports. 
The internal control system also greatly influences the quality of financial statements. This is in accordance with the objectives of the internal control system proposed by the Committee of Sponsoring Organizations of the Treadway Commission (COSO, 2013), namely to provide adequate confidence in achieving organizational goals through effective and efficient activities, reliability of financial reporting, and compliance with regulations - invitation. Based on data from the Overview of Semester 1 Results of 2017, the results of the BPK's examination of 537 Local Government Financial Statements (LKPD) revealed 6,053 SPI weaknesses consisting of 2,156 weaknesses in accounting and reporting control systems, 2,657 weaknesses in the control system for implementing revenue and expenditure budgets, and 1,240 problems with weaknesses in the internal control structure (www.bpk.go.id). Several previous studies that examined the influence of the internal control system on the quality of financial statements showed different results. Like Indriasih (2014), Afiah and Rahmatika (2014), Silviana and Zahara (2015), Kewo and Afiah (2017) research concluded that the internal control system has a positive effect on the quality of financial report.

Organizational commitment can also affect the quality of financial report. Mowday et al., (1979) revealed that a strong commitment in the organization will be able to create confidence and support and employee loyalty towards the values and goals or objectives to be achieved by the organization. The existence of organizational commitment is one of the factors that can influence the relationship between human resource competencies and the use of information technology on the quality of financial statements. Strong organizational commitment will encourage individuals to work hard to achieve organizational goals. Quality financial reports are one of the objectives of the regional government, so that the government will improve the competence of human resources and use of information technology so that the quality of financial reports increases. Nasution (2017) concluded that organizational commitment moderates / strengthens the relationship between human resource competence and the quality of local government financial reports. However, it is different from the research of Siwambudi (2016) which concluded that organizational commitment does not moderate the relationship between the relationship between human resource competencies and the quality of financial report. Based on the phenomena and findings of previous research, this study wants to examine the influence effect of human resource competence and the use of information technology on the quality of financial report with internal control system and organizational commitment as moderating variable.

\section{literature review and hypotheses \\ Stewardship Theory}

Donalson and Davis (1991) as the trigger of stewardship theory reveals that there is no situation or situation of management motivated for individual goals but management is more focused on the main goals and objectives of the organization's interests. Stewardship theory assumes there is a strong relationship between organizational satisfaction and success. According to the theory of stewardship success in an organization can be achieved by maximizing steward (management) utilities and principals. In addition, the behavior of the steward (management) will not leave his organization because the steward strives to reach the target of his organization. Stewardship theory is based on philosophical assumptions about human nature that humans can be trusted, able to act responsibly, and humans are individuals with integrity.

Stewardship theory has roots in psychology and sociology that are designed to explain situations when managers as stewards act according to the wants of owners or principals (Donalson and Davis, 1991). In the stewardship of man model, stewards maximize their utility as they achieve organizational goals rather than their self-serving goals. This study uses the theory of stewardship because this theory can explain that the community as the principal who entrusts the government as a steward to manage the organization for the success of the organization. The government as an institution that can be trusted to act in accordance with the public interest by carrying out its duties and functions appropriately and is responsible for managing regional finances and making financial accountability mandated to him, so that public services and public welfare can be achieved maximally and evenly (Haliah,2013).

\section{Goal Setting Theory}

Goal setting theory explains the relationship between goals set and work performance. Goal setting theory is part of the motivation theory that Locke put forward in 1968 with the basic concept that someone who understands the purpose or understands what the organization expects of him will influence his work behavior. Goal setting theory implies that an individual is committed to the goal (Robbins, 2008). If an individual is committed to achieving his goals, then that commitment will affect his actions and affect his performance. Achievement of the goals (objectives) that are set can be seen as the goals / level of performance that the individual wants to achieve. By using 
the goal setting theory approach, the quality of financial statements is identified as the goal. While the variable competence of human resources, utilization of information technology and organizational commitment as a determining factor. The higher the determinant factor, the higher the possibility of achieving its objectives.

\section{Hypothesis}

Competence is the ability possessed by someone / individual both of knowledge, skills and behavior to do various tasks in a particular job. Financial reports are products produced by the field of accounting science or discipline, therefore competent human resources are needed, who are supported by a background in accounting education, often attend education and training or have experience in finance. If human resources carrying out the accounting system have competencies in the field of accounting, then these resources will use their knowledge and understanding in preparing financial report in accordance with accounting principles and established rules so that they can produce quality financial reports. Competent human resources in accounting are needed to maintain the quality of financial report as outputs from the field of accounting (Haliah et al., 2015).

Some of the studies that have been conducted related to competencies such as Herdianto (2015), Silviana and Zahara (2015), and Simon et al., (2016) conclude that the competence of human resources influences the quality of financial statements. Based on the description previously stated, the first hypothesis in this study is as follows.

\section{H1:Competence of human resources has a positive effect on the quality of financial report.}

Government Regulation Number 56 of 2005 concerning the Regional Financial Information System requires local governments to utilize information technology. Information technology that is increasingly advanced facilitates the implementation of financial information because it has the strength or potential in terms of consistency of accuracy, reliability, and the ability to store large amounts of data. The use of information technology will greatly help speed up the process of managing financial transaction data, presentation of financial statements, and can avoid mistakes in preparing financial statements so that it can produce quality financial statement information.

Several studies that have been conducted related to the use of information technology and the quality of financial reports include Azlan et al., (2015) and Latjandu et al., (2016) which concluded that the use of information technology has a positive effect on the quality of financial statements. Based on the description above, then the second hypothesis stated in this study is as follows.

\section{H2: The use of information technology has a positive effect on the quality of financial report.}

Human resources who have adequate competence can present quality financial reports. The internal control system is an integral process in actions and activities carried out continuously by the leadership and all employees to provide adequate confidence in achieving organizational goals through effective and efficient activities, reliability of financial reporting, safeguarding state assets, and compliance with laws and regulations. invitation. With the existence of an internal control system, there will be division of tasks based on expertise or competence for each part of the organization. Placement of human resources based on expertise or competence will improve the quality of financial statements (Suwardi, 2018). Thus, the existence of competencies in human resources and an effective internal control system can produce quality financial report.

The results of research conducted by Fitriana and Wahyudin (2017) show that the internal control system moderates / strengthens the influence of human resource competencies on the quality of financial report. Based on the description above, the third hypothesis formulated in this study is as follows.

\section{H3: Internal control system moderates the effect of human resource competence on the quality of financial report.}

The internal control system is an integral process in actions and activities carried out continuously by the leadership and all employees to provide adequate confidence in achieving organizational goals through effective and efficient activities, reliability of financial reporting, safeguarding state assets, and compliance with laws and regulations. invitation. In the explanation of Government Regulation number 60 of 2008 concerning internal control systems, regulating control activities on system software in the form of restrictions on access to software in accordance with work responsibilities, monitoring of access and use of system software, and controlling changes made to the device soft system. Control measures are taken so that information technology is used optimally. Thus the use of information technology and strengthened by the internal control system will produce quality financial report. 
The results of the study conducted by Sukirman et al. (2013) show that internal control moderates the effect of information technology utilization on the reliability of local government financial reporting, Hardyansyah and Khalid (2016) indicating that internal control systems moderate / strengthen the influence of information technology utilization on financial report quality. Based on the description above, the fourth hypothesis is formulated in this study as follows.

\section{H4: Internal control system moderates the effect of using information technology on the quality of financial report.}

Mowday et al., (1979) revealed that strong commitment in the organization can create confidence and support as well as employee loyalty to the values and goals or objectives to be achieved by the organization. Employees who have a strong commitment to their organization will try to improve their performance and show their strong support in achieving organizational goals by maximizing their capabilities and competencies to achieve organizational goals, whereas low employee commitment tends to result in a decline in performance. This shows that strong organizational commitment can encourage employees to improve their competence in preparing financial statements in accordance with accounting principles and established rules, so that the higher organizational commitment, the higher the competence of human resources and the quality of local government financial reports.

Rahmawati (2016) and Nasution (2017) show that the interaction between the commitment of the organization and the competence of human resources influences the quality of local government financial reports. Based on the description above, the fifth hypothesis is formulated as follows.

\section{H5: Organizational commitment moderates the effect of human resource competencies on the quality of financial report.}

Mowday et al., (1979) revealed that strong commitment in the organization can create confidence and support as well as employee loyalty to the values and goals or objectives to be achieved by the organization. Employees who have a strong commitment to their organization will have responsibility and show strong support in achieving organizational goals by optimizing the use of information technology so that the financial report are timely and quality. Thus, the use of information technology and strengthened by organizational commitment will improve the quality of financial report.

Nasution (2017) concludes that the interaction between organizational commitment and the application of financial applications influences the quality of financial report, and Devi (2017) research concludes that the interaction between organizational commitment and utilization of information technology influences the quality of financial statement. Based on the description previously stated, the sixth hypothesis formulated in this study is as follows.

\section{H6: Organizational commitment moderates the effect of using information technology on the quality of financial report.}

\section{Methodology:-}

This study uses a quantitative research approach. The population in this study was 52 OPD in the Regional Government of Tana Toraja Regency. Respondents of this study are employees who carry out financial management. The sample selection technique used is non-probability with the selection of samples based on criteria (purposive sampling), namely the Head of Finance Subdivision, Officials of Financial Administration, Treasurer, and Accounting Section in the Regional Financial and Asset Management Agency. The data collection method used is a survey method with data collection techniques using a questionnaire.

The variable of Human Resource Competence in this study will be assessed using a questionnaire developed by Sudirianti (2015), as an indicator of competency in human resources, namely: (1) Knowledge; (2) Skills; and (3) Behavior. Variables of Information Technology Utilization are measured using 2 (two) indicators developed by Agustina (2015), as indicators of information technology utilization, namely: (1) Computer Usage and (2) Network Use. Internal Control System variables are measured using 5 (five) indicators developed by Rijalulfikri (2017), as indicators of internal control systems, namely: (1) Control Environment; (2) Risk Assessment; (3) Control Activities; (4) Information and Communication; (5) Monitoring. Organizational Commitment variables are measured using indicators adopted from the Organizational Commitment Questioner by Mowday et al., (1979). The instrument related to the Financial Report Quality variable will be measured using an instrument adopted from the Satriani (2017) study which was processed from PP No. 71 of 2010 as many as four indicators, namely: (1) relevant; 
(2) reliable; (3) can be compared; and (4) can be understood. This questionnaire will be measured using a Likert scale from 1 to 5. The analytical model used to test hypotheses is to use Moderated Regression Analysis (MRA).

\section{Result And Discussion:-}

The Effect of Human Resource Competence (X1) on Quality of Financial Report (Y)

The results of the regression analysis for the relationship between human resource competencies and the quality of financial report have a probability value of $0,000(<0.05)$. This value indicates that the relationship between human resource competency and financial report quality has a significant effect. In addition, the coefficient for the competency variable is 0,270 which indicates that the direction of the relationship between human resource competencies and the quality of financial report is positive. The coefficient value that is positive indicates the direction of the relationship. Thus, hypothesis 1 which states that "human resource competencies have a positive effect on the quality of financial report" is accepted.

The results of this study are in line with several previous studies namely Herdianto (2015), Silviana and Zahara (2015), and Simon et al., (2016) which show that the competence of human resources influences the quality of financial report.

\section{The Effect of The Use Of Information Technology (X2) on Quality of Financial Report (Y)}

The results of the regression analysis for the relationship between the use of information technology and the quality of financial report have a probability value of $0,000(<0.05)$. This value indicates that the relationship between the use of information technology and the quality of financial report has a significant effect. In addition, the coefficient for the information technology utilization variable is 0.792 which indicates that the direction of the relationship between the use of information technology and the quality of financial report is positive. The coefficient value that is positive indicates the direction of the relationship. Thus, hypothesis 2 which states that "the use of information technology has a positive effect on the quality of financial report" is accepted.

The results of this study are in line with several previous studies that have examined the relationship between the use of information technology and the quality of financial reports, such as Azlan et al., (2015) and Latjandu et al., (2016) which concluded that the use of information technology has a positive effect on the quality of financial report.

The Effect of Interaction between Human Resource Competence (X1) and Internal Control System (Z1) on Quality of Financial Report (Y)

The results of the regression analysis for interactions between human resource competencies and internal control systems have a probability value of $0.001(<0.05)$. This value indicates that the internal control system can moderate the influence of human resource competencies on the quality of financial report. The coefficient for interaction of human resource competency variables and internal control systems is positive at 0.004 , which means that the internal control system variables strengthen the influence of human resource competencies on the quality of financial statements. Thus, hypothesis 3 which states that "internal control systems can moderate the influence of human resource competencies on the quality of financial report" is accepted.

This research is in line with the results of research conducted by Fitriana and Wahyudin (2017) showing that the internal control system moderates / strengthens the influence of human resource competencies on the quality of financial report.

The Effect of the Interaction between the Use of Information Technology (X2) and the Internal Control System (Z1) on the Quality of Financial Report (Y)

The results of the regression analysis for the interaction between the use of information technology and internal control systems have a probability value of $0,000(<0.05)$. This value indicates that the internal control system can moderate the influence of the use of information technology on the quality of financial report. The coefficient for the interaction of the variable information technology utilization and internal control system is positive at 0.014 , which means that the internal control system variable strengthens the effect of information technology utilization on the quality of financial report. Thus, hypothesis 4 which states that "internal control systems can moderate the effect of information technology utilization on the quality of financial report" is accepted. 
This research is in line with the results of a study by Sukirman et al. (2013) showing that internal control moderates the effect of information technology utilization on the reliability of local government financial reporting and Hardyansyah and Khalid (2016) indicating that internal control systems moderate / strengthen the influence of information technology on quality financial report.

The Effect of Interactions between Human Resource Competence(X1) and Organizational Commitment (Z2) on Quality of Financial Report (Y)

The results of the regression analysis for interactions between human resource competencies and organizational commitment have a probability value of $0.004(<0.05)$. This value indicates that organizational commitment can moderate the influence of human resource competencies on the quality of financial report. The coefficient for interaction of human resource competency variables and organizational commitment is positive at 0.004 , which means that the organizational commitment variable strengthens the influence of human resource competencies on the quality of financial report. Thus, hypothesis 5 which states that "organizational commitment can moderate the influence of human resource competencies on the quality of financial report" is accepted.

This finding is in line with the research of Rahmawati (2016) and Nasution (2017) showing that the interaction between the commitment of the organization and the competence of human resources influences the quality of the financial report of the local government.

\section{The Effect of Interactions between the Use of Information Technology (X2) and Organizational Commitment} (Z2) on Quality of Financial Report (Y)

The results of the regression analysis for the interaction between the use of information technology and organizational commitment have a probability value of $0,000(<0.05)$. This value indicates that organizational commitment can moderate the influence of the use of information technology on the quality of financial report. The coefficient for the interaction of the variable use of information technology and organizational commitment is positive at 0.017 , which means that the variable organizational commitment strengthens the influence of the use of information technology on the quality of financial report. Thus, hypothesis 6 which states that "organizational commitment can moderate the influence of information technology utilization on the quality of financial report" is accepted.

The results of this study are in line with several previous studies such as the results of Nasution's research (2017) and Devi's (2017) study concluded that the interaction between organizational commitment and the use of information technology affects the quality of financial report.

\section{Conclusions And Recommendation:-}

Human resource competence has a significant effect on the quality of financial report, the use of information technology has a significant effect on the quality of financial report, internal control systems moderate and strengthen the effect of human resource competence on quality of financial report, internal control system moderate and strengthen the effect of the use of information technology on quality of financial report, organizational commitment moderates and strengthens the influence of human resource competence on the quality of financial report, organizational commitment moderates and strengthens the effect of the use of information technology on the quality of financial report.

The results of this study could have implications for the government to consider the factors in this study which are considered to have an effect on the quality of financial report. Subsequent research should be expanded by increasing the population in several district governments, considering that the population in this study is only in the OPD of Tana Toraja Regency. 


\section{References:-}

1. Afiah dan Rahmatika. 2014. Factors Influencing the Quality of Financial Reporting and Its Implications on Good Government Governance (Research on Local Government Indonesia). International Journal of Business, Economics and Law. Vol. 5, Issue 1 (Dec.) ISSN 2289-1552.

2. Agustina, Lia. 2015. Pengaruh Pengendalian Intern, Pemanfaatan Teknologi Informasi dan Kompetensi Sumber Daya Manusia terhadap Kualitas Laporan Keuangan dengan Pengawasan Keuangan Daerah sebagai Variabel Pemoderasi (Studi pada Kabupaten Aceh Tamiang). Tesis. Medan: Universitas Sumatera Utara.

3. Andre, Maria Mayella. 2017. Analisis Faktor-Faktor yang Memengaruhi Kualitas Informasi Pelaporan Keuangan Pemerintah Daerah (Studi Pada Studi pada Satuan Kerja Perangkat Daerah di Pemerintah Kota Yogyakarta). Tesis. Yogyakarta: Program Pascasarjana Fakultas Ekonomi dan Bisnis Universitas Gajah Mada.

4. Azlan Muhammad, Titiek Herwanti, dan Endar Pituringsih. 2016. Pengaruh Kualitas Sumber Daya Manusia, Pemanfaatan Teknologi Informasi, Pengendalian Intern Akuntansi, dan Pengawasan Keuangan Daerah terhadap Keandalan Laporan Keuangan Daerah pada SKPD Pemerintah Kabupaten Lombok Timur. Jurnal Magister Akuntansi. Mataram: Program Pascasarjana Universitas Mataram.

5. Committee of Sponsoring Organizations of The Treadway Commission (COSO). 2013. Internal Control Integratet Framework. AICPA Publication.

6. Devi, Prima Citra. 2017. Analisis Faktor-Faktor yang Mempengaruhi Kualitas Laporan Keuangan SKPD di Pemerintah Kota Binjai dengan Komitmen Organisasi sebagai Variabel Moderating. Tesis. Medan. Program Magister Akuntansi Fakultas Ekonomi dan Bisnis Universitas Sumatera Utara.

7. Donaldson, L. dan Davis, J.H. 1991. Stewardship Theory or Agency Theory: CEO Governance and Shareholder Returns. Australian Journal of Management, Vol 16, No. 1.

8. Fitriana dan Agus Wahyudin. 2017. Factors Influencing The Quality of Financial Reporting on Local Government of Purbalingga. Accounting Analysis Journal. ISSN 2252-6765

9. Haliah. 2013. Kualitas Informasi Laporan Keuangan dan Faktor yang Memengaruhinya (The Quality of Information in Local Government Financial Statement and the Influential Factors).Disertasi. Makassar: Program Pascasarjana Universitas Hasanuddin.

10. Haliah, Abdul Hamid Habbe, dan Muhammad Irdam Ferdiansah. 2015. The Role of Information Technology as Moderating Variable and Internal Control Effectiveness as Intervening Variable in the Relationship between Human Resource Competency and Internal Auditor Service Quality on Quality of Report. Faculty of Economics and Bussiness Accounting Department Hasanuddin University.

11. Hardyansyah dan Khalid. 2016. Pengaruh Kompetensi Sumber Daya Manusia dan Pemanfaatan Teknologi Informasi terhadap Kualitas Laporan Keuangan dengan Sistem Pengendalian Intern sebagai Variabel Moderasi pada SKPD Kabupaten Polewali Mandar. Jurnal Akuntansi Peradaban: Vol. I No. 1 Januari 2016

12. Herdianto. 2015. Pengaruh Faktor Teknis dan Organisasional terhadap Kualitas Laporan Keuangan (Studi pada Kementrian Ketenaga Kerjaan Republik Indonesia). Tesis. Yogyakarta: Program Pascasarjana Fakultas Ekonomika dan Bisnis Universitas Gadjah Mada.

13. Indriasih, Dewi. 2014. The Effect of Government Apparatus Competence and the Effectiveness of Government Internal Control Toward the Quality of Financial Reporting in Local Government. Research Journal of Finance and Accounting, ISSN 222-1697(Paper) ISSN 2222-2847 (Online) Vol. 5, No. 20, 2014

14. Kewo dan Afiah. 2017. Does Quality of Financial Statement Affected by Internal Control System and Internal Audit ?. International Journal of Economics and Financial Issues. ISSN: 2146-4138.

15. Locke, E. A. 1968. Toward a Theory of Task Motivation and Incentives. Organizational Behavior and Human Performance, 3, 157-189

16. Latjandu Imelda, Kalangi Lintje, dan Jantje J. Tinangon. 2016. Faktor-Faktor yang Mempengaruhi Kualitas Laporan Keuangan Pemerintah Daerah di Kabupaten Talaud. Tesis. Manado: Program Pascasarjana Fakultas Ekonomi dan Bisnis Universitas Sam Ratulangi.

17. Mahmudi. 2016. Analisis Lapoan Keuangan Pemerintah Daerah. Edisi Ketiga, Yogyakarta: UPP STIM YKPN.

18. Mowday, R. T., Steers, R. M., \& Porter, L. W. 1979. The Measurement of Organizational Commitment. Journal of Vocational Behavior, Vol.14.

19. Nasution, Fauzi Fahdi. 2017. Pengaruh Kompetensi SDM, Penerapan Aplikasi Keuangan, Penerapan Standar Akuntansi Pemerintahan terhadap Kualitas Laporan Keuangan Pemerintah Provinsi Sumatera Utara dengan Komitmen Organisasi sebagai Variabel Moderating. Tesis. Medan: Program Pascasarjana Fakultas Ekonomi dan Bisnis Universitas Sumatera Utara

20. Peraturan Pemerintah Nomor 71 Tahun 2010 tentang Standar Akuntansi Pemerintahan. 2010. Jakarta: Sekretariat Negara. 
21. Peraturan Pemerintah Nomor 56 tahun 2005 tentang Sistem Informasi Keuangan Daerah. 2005. Jakarta: Presiden Republik Indonesia.

22. Peraturan Pemerintah No. 60 Tahun 2008 Tentang Sistem Pengendalian Intern Pemerintah. 2008. Jakarta: Presiden Republik Indonesia.

23. Prapto, Susilo. 2010. Pengaruh Pemanfaatan Teknologi Informasi, dan Pengendalian Intern Akuntansi Terhadap Keterandalan dan Ketepatwaktuan Pelaporan Keuangan Pemerintah Daerah (Studi Pada Pemerintah Kabupaten Sragen). Tesis. Surakarta: Program Pascasarjana Fakulas Ekonomi dan Bisnis Universitas Sebelas Maret.

24. Rahmawati, D. 2016. Pengaruh Kapasitas Sumber Daya Manusia Terhadap Kualitas Laporan Keuangan Pemerintah Daerah Dengan Komitmen Organisasi Sebagai Pemoderasi (Studi Empiris Pada Pemerintah Kab.Sragen)http://ejournal.feunsa.web.id/index.php/Smooting/article/view/148/130

25. Rijalulfikri, Muhammad. 2017. Pengaruh Sistem Pengendalian Intern, Teknologi Informasi, dan Kompetensi Sumber Daya Manusia terhadap Kualitas Laporan Keuangan (Studi Empiris pada Pemerintah Kabupaten Jeneponto) Tesis. Makassar: Program Magister Akuntansi Fakultas Ekonomi dan Bisnis Universitas Hasanuddin

26. Robbins, Stephen P. 2008. Perilaku Organisasi, PT. Salemba Empat, Jakarta

27. Satriani. 2017. Pengaruh Sistem Pengendalian Intern, Kompetensi Sumber Daya Manusia dan Komitmen Organisasi terhadap Kualitas Laporan Keuangan (Studi Empiris pada Pemerintah Kabupaten Toli-Toli). Tesis. Makassar: Program Magister Akuntansi Fakultas Ekonomi dan Bisnis Universitas Hasanuddin.

28. Silviana, dan G. Zahara. 2015. The influence of Competence Local Government Agencies and The Implementation Government of Internal Control System toward the Quality of Local Government Financial Statement. Research Journal of Finance and Accounting ISSN 2222-1697 (Paper) ISSN 2222-2847 (Online). Vol.6, No.11, 2015.

29. Simon, Yulius, Mahfudnurnajamuddin, Masdar Mas'ud, Muhammad Su'un. 2016. The Role of Apparatus Comptence, Internal Control System on Good Governance and The Quality of Financial Statement Information (Research on Regional Work Unit Selayar Islands District). Journal of Arts, Science \& Commerce. Vol.- VII, Issue-4, Oct. 2016 ISSN 2231-4172

30. Siwambudi, I Gusti Ngurah. 2016. Komitmen Organisasi Memoderasi Pengaruh Kompetensi Sumber Daya Manusia dan Sistem Pengendalian Intern terhadap Kualitas Laporan Keuangan Pemerintah Daerah Kabupaten Klungkung. Tesis. Denpasar. Program Pascasarjana Fakultas Ekonomi dan Bisnis Universitas Udayana.

31. Sudiarianti, Ni Made. 2015. Pengaruh Kompetensi Sumber Daya Manusia pada Penerapan Sistem Pengendalian Intern Pemerintah dan Standar Akuntansi Pemerintah serta Implikasinya pada Kualitas Laporan Keuangan Pemerintah Daerah.Tesis. Denpasar: Program Pascasarjana Universitas Udayana.

32. Sukirman Sularso, Havid Nugraheni dan Erly Setyowati. 2013. Faktor-Faktor yang Mempengaruhi Keterandalan dan Ketepatwaktuan Pelaporan Keuangan dengan Pengendalian Intern Akuntansi sebagai Variabel Pemoderasi (Studi Empiris pada Pemerintah Daerah Kabupaten Banyumas. Journal Proceeding Fakultas Ekonomi Universitas Jenderal Soedirman, 3 (1).

33. Suwardi, Adriani. 2018. Pengaruh Kompetensi Sumber Daya Manusia dan Pemanfaatan Teknologi Informasi terhadap Kualitas Laporan Keuangan dengan Penerapan Pengendalian Intern sebagai Variabel Moderasi.Tesis. Makassar: Program Pascasarjana Universitas Hasanuddin.

34. Syarifudin, Akhmad. 2014. Pengaruh Kompetensi SDM dan Peran Audit Intern terhadap Kualitas Laporan Keuangan Pemerintah Daerah dengan Variabel Intervening Sistem Pengendalian Internal Pemerintah (Studi Empiris pada Pemkab Kebumen). Jurnal Fokus Bisnis, Vol.14. No.02 Desember 2014, Hal.26-44.

35. Wilkinson, W. Joseph, Michael J. Cerullo, Vasant Raval, \& Bernard Wong-On-Wing. 2000. Accounting Information Systems: Essential Concepts and Applications. Fourth Edition.John Wiley and Sons.Inc.

36. www.dprd-tanatorajakab.go.id

37. www.bpk.go.id 